\title{
PRINCIPAL AND IMPORTANT FACTORS IN THE FORMATION OF SOCIAL ACTIVITY STUDENT WOMEN
}

\section{Dilnavoz Tolqin qizi Tursunova}

Lecturer Department of Preschool Education Fergana State University

\section{ABSTRACT}

The article analyzes the principles of renewal and succession in the formation of involvement of women in reforms, the state youth policy, comprehensive reforms in all spheres of life, the processes of radical change in society.

KEYWORDS:- Social activism, family institution, reproductive, women, civil society, heredity, modern worldview

\section{INTRODUCTION}

Increasing the socio-political and social activity of women in Uzbekistan, creating conditions for them to realize their abilities and potential in various fields and sectors, ensuring unconditional respect for their rights and legitimate interests, comprehensive support for motherhood and childhood, as well as the family. On February 2, 2018, the Decree of the President of the Republic of Uzbekistan No. PF-5325 "On measures to radically improve the activities in the field of support of women and strengthening the institution of the family" was issued. The adoption of this decree indicates that there are a number of systemic problems and shortcomings that hinder the full support of women and the organization of targeted work with them to create effective mechanisms for strengthening the spiritual and moral environment in families and health:

- There is no effective system for the prevention and treatment of maternal and perinatal diseases, especially in remote rural areas, where the activities to protect women's reproductive health are insufficiently organized;

- There are no effective measures for the prevention of delinquency and crime among women, the mechanism for improving the legal culture of women, providing them with legal advice does not meet modern requirements;

- The wide range of tasks of women's committees does not allow them to fully mobilize their efforts 
CURRENT RESEARCH JOURNAL OF PEDAGOGICS 2(5): 53-62, May 2021

DOI: https://doi.org/10.37547/pedagogics-crjp-02-05-11

ISSN 2767-3278

(C)2021 Master Journals

\section{Crossref do) 81 Google}

Accepted 23th May, 2021 \& Published 28 ${ }^{\text {th }}$ May, 2021

and capabilities to address the most important issues of women in the absence of the necessary powers and organizational units. In order to overcome the above problems and radically improve the activities in the field of support of women and strengthening the family, as well as taking into account the tasks set out in the Action Strategy for 2017-2021, the activities of the Women's Committee of Uzbekistan Priorities have been identified:

- Ensuring the effective implementation of state policy to support women, protect their rights and legitimate interests, and increase their role and activity in the socio-political life of the country;

- Timely identification of women's problems, compiling address lists of women in need and in difficult social situations, providing them with socio-legal, psychological and financial assistance;

- Comprehensive targeted support for women's employment, improving working conditions, especially in rural areas, the involvement of young girls in family and private entrepreneurship, handicrafts;

- Close cooperation with government agencies and civil society institutions in the early prevention of delinquency among women, especially in the implementation of individual work with those who are prone to delinquency, as well as in the implementation of measures for social rehabilitation and adaptation of women released from prisons ensuring cooperation.

Materials and methods

The achievement of independence of our country, as well as in all spheres of society and people's life, has made radical changes in the role and importance of youth in social and economic processes. Due to the strengthening of the legaldemocratic, civil society based on market relations, which is an integral part of this process, it is important today to study the views of the state on youth policy and changes in the image of the younger generation as a result of social relations. is growing.

In this context, the state policy on women has to take into account the changes in the social basis of society in the current context of strengthening market relations, new groups emerging as a result of stratification among young people, as well as the principles that ensure their diversity. It is on the basis of these principles that the social basis and economic factors on which this policy is based are formed.

It is known that the proper organization of activities in this area can not only ensure the development of society, but also the development of socio-political processes, which will have a positive impact on many other areas, even its management. Therefore, in the system of social sciences, with the state youth policy, this issue needs to be studied in depth, especially in social philosophy, sociology and political sciences.

Result and discussion

Today's era in which women understand themselves is characterized by two characteristics. First, there is a system of national and universal values that has long been passed down from generation to generation in the sociopolitical reality. Second, the system of liberal values inherent in modern societies, which sometimes embodies the ideas of individual individualism, has an impact on young people. At the same time, the ongoing stratification in society, the process of division of social strata into diverse groups, increases the demand for the formation of patriotic and nationalistic features in young people several times. As a result, the rich - the poor, the natives - the foreigners, the townspeople - the peasants, the "ours" - the "others", the nobles - the uncles, the lucky - the unlucky, the leaders - the outsiders (the marginalized) are different and completely 
different strata. the need for a single ideology, a single ideological system that can unite, focus on common goals, and be mutually agreeable and co-operative is on the agenda.

In today's intense and controversial world, shaping women's thinking in the spirit of nationalism naturally makes the issue of protecting young people from ideological threats a pressing issue. Because, as Sh. Pakhrutdinov noted, "Threat is a socio-political situation, which in a certain historical period is aimed at weakening the political foundations of the state as a social system, as well as disrupting human life, disrupting life in general. , occurs due to the influx of planetary factors. This, in turn, requires the development of a system of necessary measures, the implementation of which will lead to significant positive changes in the country. [1].

The last few years have been marked by dramatic changes around the world. As a result, maintaining their national freedom and liberty at the borders of a world prone to political change is a priority.
The formation of the content of a new modern policy on women in response to various modern threats is a necessity that has risen to the level of not only political but also universal demand. Therefore, the state should strengthen its investment and innovation character among young people, and in its implementation should introduce a system of special programs in a preventive manner. In this regard, unorganized youth require the improvement of new institutional technologies, strengthening systems of work with youth, ensuring their diversity, methodological and methodological knowledge of personnel working with youth. Strengthening the principles of working with young people is to attract social investment, ensure the innovative development of young people, the effective use of their initiatives.

At the same time, there is a lack of coordination among women in the activities of various state and public organizations. 


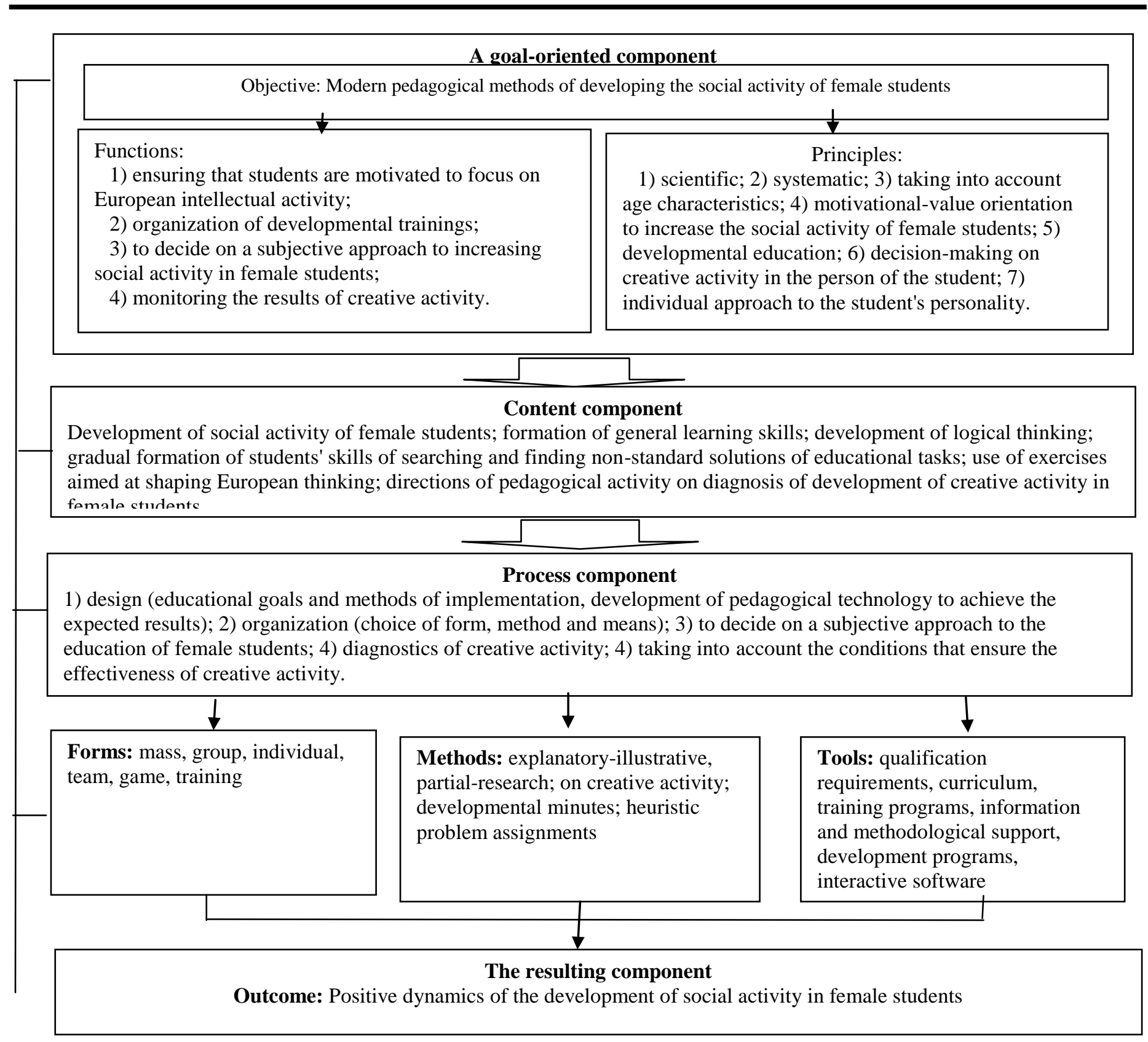

So, today it is necessary to create a modern networked infrastructure of youth, regular analysis and financing of its activities. Management of social activity of youth through various systems of non-governmental and public organizations, as well as the direction of state development serve the holistic implementation of youth and state goals. In this sense, the development of various systems aimed at 
meeting the needs of young people for modern information, the well-organized work of information-analytical, educational, technical centers will allow unorganized youth to study scientifically, comparatively and scientifically. It is also a requirement of the time to create a single methodological standard for the scientific study of youth issues.

- $\quad$ New modern methods of working with young people require a variety of activities aimed at the well-being of their activities and the formation of their thinking, the general efforts of such disciplines as political science, sociology, pedagogy, psychology, ie scientific research. It is a pressing issue to reform and implement all modern methods of working with young people on the basis of national interests. Today, the youth itself is characterized by diversity, diversity, diversity of interests. On the basis of this diversity, the correct definition of work methods for each young person, educating him in the spirit of democratic values is an effective form of protecting young people from destructive ideas. At the same time, internal conflicts in society increase based on the diversity of interests. At the same time, it is natural that the main goal is to unite young people around different interests - to build a civil society, which will be the basis for future stability, peace and prosperity. Therefore, when working with young people:

- application of all new methods of cooperation with the public;

- $\quad$ effective use of new political technologies and methods of influencing public opinion;

- pay more attention to the methods of public relations, ie PR campaigns;

- $\quad$ Orientation of young people to the goals that are important for the development of the state, based on an in-depth study of the growth trends of their interests and thinking;
- to achieve the practical application of democratic values such as freedom, equality, prudence, human rights, personal independence, the rule of law, personal and public interests, methods of participation in public administration, civic responsibility, the ability to integrate their interests with public and state interests;

- In working with young people, the main focus should be on ways of solidarity, stability, mutual trust and cooperation in society;

- $\quad$ increasing the demand for staff working with young people;

- $\quad$ Collection of information and evidence on the socio-economic situation of young people, their analysis, effective delivery of information to young people;

- practical application of the tendencies of consensus, openness, transparency, fearlessness, equality, transparency in working with young people;

- $\quad$ Formation of a differentiated approach to working with young people, the system of new pedagogical technologies, the use of individual, group, community outreach, as well as the widespread introduction of interactive methods.

The traditional method of conducting meetings today justifies itself only in the activity of conveying short and clear information. Meetings are losing their power to influence the public. But the meeting system is a convenient way to quickly organize, include in reports, campaign. This means that it is impossible to prepare the minds of young people for complex processes. Therefore, the appropriate use of the method of meetings, the widespread use of other methods of working with young people is an effective means of shaping their thinking on the basis of the necessary values.

Also, the scientific and theoretical development of modern methods and tools for working with 
CURRENT RESEARCH JOURNAL OF PEDAGOGICS 2(5): 53-62, May 2021

DOI: https://doi.org/10.37547/pedagogics-crjp-02-05-11

ISSN 2767-3278

(C)2021 Master Journals

\section{Crossref do) 81 Google}

Accepted 23 ${ }^{\text {th }}$ May, 2021 \& Published 28 $8^{\text {th }}$ May, 2021

women is one of the urgent tasks facing the science of political science. Political processes in young people, the formation of a positive attitude to the ongoing reforms in the country, arousing their interest in the system of political values, increasing their political and legal knowledge, harmonizing the interests of the state and youth, ensuring cooperation depends on modern methods and tools of working with youth. The introduction of direct vertical and horizontal communication between young people and the state, that is, information communications and transparency, will serve to increase their sense of trust and commitment to innovation. "... as information and communication technologies develop, along with the use of its advantages and conveniences, ensuring information security throughout the country is becoming a topical issue" [2].

Thus, a brief analysis of the principles of renewal and succession in the formation of involvement of women in reform is carried out in connection with the youth policy of our state, comprehensive reforms in all spheres of life, the process of radical change in society. From the very beginning of independence, the state youth policy has focused on issues such as social protection, active participation in building a democratic and civil society, ensuring their rights and interests, further expanding their opportunities in various fields. At the same time, the tradition of looking at young people as a factor that creates an "explosive" effect on the development of society, the main force that forms the country's human resources, as a base and support in future creative activities. Today, the youth policy aimed at renewal and stabilization of the principles of succession in the formation of involvement of young people in reforms is being implemented in the country in close connection with the goals of further deepening democratic reforms and development of civil society. This, in turn, indicates that it has entered a new phase of state youth policy, has grown in quality, improved and is being implemented effectively.

Given the current market relations in our society and the strengthening of the socio-economic foundations of state youth policy, it is important to analyze them not only in theory but also in practice, given the significant changes in the system in this area at this stage of transition. earns.

From the point of view of social philosophy, it should be noted that the events and processes related to the socio-economic foundations of state youth policy are studied in a dialectical relationship and form a single social object. It is obvious that we need to recognize the specific events and processes inherent in the policy of our state in this direction as some elements of this holistic system.

The experience of modern Uzbekistan shows that the results of reforms in all spheres of life over the past years of independence, the revival of national spirituality, extensive study of our rich national historical heritage, preservation of traditions, development of culture and art, science and education issues. Reforms in these areas and their high results today clearly show that not only the economic and political factors, but also the spiritual foundations, aimed at ensuring the effective implementation of this policy, are based on an extremely solid foundation.

Some scholars who have studied this aspect of the matter believe that an effective youth policy is the result of centuries of development of Western civilization and today its achievements are reflected in this field. But a broad analysis of the issue, especially an in-depth study of the legacy of Eastern encyclopedic scholars, clearly shows that these views are one-sided in nature, in which more European-centric tendencies predominate. At the same time, the analysis 
CURRENT RESEARCH JOURNAL OF PEDAGOGICS 2(5): 53-62, May 2021

DOI: https://doi.org/10.37547/pedagogics-crjp-02-05-11

ISSN 2767-3278

(C)2021 Master Journals

\section{Crossref do) 81 Google}

Accepted 23th May, 2021 \& Published 28 ${ }^{\text {th }}$ May, 2021

shows that the principles of youth education of the peoples of the East and the spiritual factors and national traditions formed as a result of long historical development in this area are one of the important foundations for organizing and implementing state youth policy in modern Uzbekistan. In this sense, "... a deep study of Eastern philosophy, on this basis to revive the roots of our great culture and values, get rid of the ideology left over from our recent past, restore our national ideology and thinking left to us by our great ancestors, enrich it with modern universal spirit it is the urgent task of all of us. "[3]

It should be noted that the process of effective formation of state policy on youth in any country, based on science and modern principles, requires radical changes in the social, economic, political, legal, spiritual and cultural spheres of society. Today, the study of foreign experience in this area, in particular, the analysis of works published in the West, clearly shows that more attention is paid to the economic, legal and political aspects of this process, and insufficient attention is paid to the spiritual and moral foundations.

The economic security of a society, or the adoption of relevant laws alone, cannot fully shape an effective youth policy of the state. One of the most important tasks of this policy is to change the consciousness and spirituality of young people and to bring them into the world of modern thinking. The role and importance of spiritual factors in carrying out such an extremely complex and multifaceted task is incomparable. While some scholars from near and far in the former Soviet Union have praised the Western experience in the early years of their independence and sought to relocate it to their own countries, they have forgotten what the roots and foundations of the spiritual decline in Western society are and what the consequences are. they had put. The recent history of these countries clearly shows the tragic consequences of this.

Therefore, it is no coincidence that our ancestors knew that spirituality and enlightenment, which have long been an invaluable asset, are one of the main conditions for the education of young people, human perfection and development of the nation. As Imam Abu Hamid al-Ghazali put it in Hujjat al-Islam, "Chemistry of Happiness": "Man is a creature between an angel and an animal. The animal does not develop because it does not have the power to mature. The angel does not develop either, because he is a pure divine light, because only human beings have the character of development, spiritual maturity. "[4]

There is no doubt that spiritual education is a requirement for development, a specific factor in the development of society. But at the same time it is one of the most important factors that determine the essence of the principles that occupy the moral image, heart and mind of young people, that is, have a great impact on the spirituality of the emerging generation.

Thanks to this continuous and comprehensive process, the protection of the population of our country, especially our inexperienced young people, from the influence of foreign and alien ideas, the formation of their independence and modern worldview is becoming one of the most important aspects of our state policy. But it is not that there are no problems in this area, there are many pressing issues that need to be addressed.

In this regard, as noted in the Resolution "On increasing the effectiveness of spiritual and educational work and raising the development of the industry to a new level" signed by President Shavkat Mirziyoyev, during the years of independence to strengthen the spiritual and enlightenment foundations of society, the basic concepts and principles of national independence. especially in the hearts of the younger generation, a system of propaganda 
CURRENT RESEARCH JOURNAL OF PEDAGOGICS 2(5): 53-62, May 2021

DOI: https://doi.org/10.37547/pedagogics-crjp-02-05-11

ISSN 2767-3278

(C)2021 Master Journals

\section{Crossref do) 81 Google}

Accepted 23th May, 2021 \& Published 28 ${ }^{\text {th }}$ May, 2021

aimed at increasing the sense of involvement and responsibility for the fate and future of our country, the formation of ideological immunity against foreign ideas. In this regard, the Republican Council for Spirituality and Enlightenment, the Republican Center for Spiritual Propaganda, the National Research and Practice Center for Ideas and Ideology and its local branches have done some work.

At the same time, the processes of globalization are intensifying in the world, the number of new threats and hotbeds of aggression is increasing, which is becoming more and more dangerous, which requires a new level of spiritual and educational work. This requires solving a number of problems that have accumulated in the industry. Including,

The content of spiritual and enlightenment work is limited to the celebration of holidays, glorious dates, and propaganda work aimed at raising the socio-political, legal, economic, moral culture of our people does not meet the strategic requirements for further development of our country;

Although the bulk of the spiritual threats aimed at capturing the minds and hearts of our youth are carried out through the Internet, in practice they are limited to the traditional form of propaganda;

the preventive system is not established in propaganda work, preventive propaganda technologies aimed at preventing the impact of moral threats are not used;

there is no stable system of remuneration of employees of district (city) departments in the field of national ideology and spirituality;

due to the lack of systematic management of the sector, the improvement of knowledge, skills and abilities of employees has not been carried out consistently;

The quality of teaching social sciences and humanities in higher education institutions, in particular, the tasks set for bachelors and masters in the field of national ideology and spirituality do not meet today's requirements, which does not allow them to become fullfledged professionals in ideological struggle;

The invaluable spiritual wealth of our people in the upbringing of young people in the family, neighborhood and educational institutions - the insufficient introduction of national methods of education has led to a decline in kindness, family harmony, respect for the elder, less respect for women. became a problem.

In our country, a number of measures are being taken to eliminate these cases, to create a healthy spiritual environment among young people, to increase their socio-political activity and legal culture. Indeed, as noted by President Sh. Mirziyoyev, "special attention should be paid to raising the legal culture in society, strengthening respect for the law among citizens and encouraging people who are actively involved in the fight against crime" [5]. However, there are still negative cases among young people, such as suicide, drug and alcohol use, and HIV / AIDS.

\section{Conclusion}

Based on the above, it should be noted that there has been an increase in suicides and assassinations, drug and alcohol abuse, and the incidence of AIDS and HIV among young people throughout the country. This is primarily due to the fact that local authorities do not pay enough attention to these areas, do not study the main factors that cause them, and do not develop measures to prevent and eliminate them.

In this context, the issue of raising the spiritual world of the younger generation, educating them in the spirit of national and universal values, the formation of high moral principles in its image remains the most pressing tasks of state youth policy. At the same time, today, within the 
framework of this policy, along with many factors, the methods of spiritual influence and the effective use of moral education are of great importance in the formation of a harmoniously developed generation that has mastered modern knowledge, intellectual potential and advanced technologies. At the same time, "In order to protect students from various spiritual threats, it is necessary to strengthen the influence of the family environment in which it is formed. Increasing the responsibility of parents in the family environment, the role of teachers, class teachers and deputy heads of spiritual and educational work of all educational institutions in the formation of the spirituality of students is very important in the current information age. It is also necessary to strengthen the cooperation of educational institutions, family and community social institutions with the media "[6].

At the same time, it is no coincidence that the current development of Uzbekistan and the Action Strategy pay special attention to this issue, along with economic, social, political and legal factors of social development and youth development, further strengthening its spiritual, educational and moral foundations. Indeed, in today's world of globalization and information, it is difficult to say that people in any country or anywhere in the world, especially young people, are fully protected from the influence of foreign ideas.

In this regard, it should be noted that the state policy on youth is not a simple set of fixed and never-changing constants, but a set of methods and tools, measures, various programs that are constantly updated and modernized under the influence of society and the requirements of the times.

In this sense, its realization in any period means that it is a deeply dialectical process and requires constant change and renewal. The following opinion of President Shavkat Mirziyoyev is a very important theoretical guideline in defining and understanding the main goals and priorities of state youth policy today: we need to further increase vigilance and awareness in the matter. We must raise our children ourselves, not leave them in the hands of others. To do this, we need to talk more with our young people, listen to their hearts, know their pain, give them practical help to solve their problems. We need to pay special attention to working with unorganized youth in this regard. In carrying out these tasks, we rely on our national traditions, the rich heritage of our ancestors, formed over the centuries. We will do our best to ensure that our children, especially girls, acquire modern knowledge and skills, foreign languages, become healthy and well-rounded in all respects, and find a worthy place in life."[7]

It is clear from this view that the values, ideals and principles inherent in today's youth of independence cannot be determined without the formation of highly spiritual people, ie a spiritually mature generation, in the implementation of youth policy. It is clear that his profound words were not uttered in vain. These words are as important and relevant today as they were at the beginning of the last century.

\section{REFERENCES}

1. Пахрутдинов Ш. Тахдид - халокатли куч. - Тошкент: Академия, 2001. - 11-12б.

2. Mirziyoev Sh.M. Speech at the joint session of the chambers of the Oliy Majlis dedicated to the inauguration of the President of the Republic of Uzbekistan. The word of the people. December 15, 2016. 
CURRENT RESEARCH JOURNAL OF PEDAGOGICS 2(5): 53-62, May 2021

DOI: https://doi.org/10.37547/pedagogics-crjp-02-05-11

ISSN 2767-3278

(C)2021 Master Journals

crossref do) 801 Google

Accepted 23th May, 2021 \& Published 28 ${ }^{\text {th }}$ May, 2021

3. Ғуломов С. Маънавий ривожланиш миллий тикланиш омили // Фалсафа ва хуқуқ. - Тошкент: 2008. - Махсус сон. - 9 б.

4. Абу Хомид Ғаззолий. Кимиё саодат. Тошкент: Адолат, 2005. 29 бет.

5. Mirziyoev Sh.M. Consistent continuation of democratic reforms, creation of a peaceful and decent standard of living for our people is a guarantee of sustainable development. // URL http://uzlidep.uz/uzc/news/ demokratikislokhotlarni-izchil-davom-ettirishhalkimiz-uchun-tinch-va-osoyishtamunosib-khayot

6. Тайлакова Ш.Н. $\begin{gathered}\text { Ўқувчи } \\ \text { маънавиятини }\end{gathered}$ оммавий
ахборот воситалари асосида такомиллаштириш (телекўрсатувлар, радиоэшиттиришлар ва интернет хабарлари мисолида). Педагогика фанлари бўйича фалсафа доктори (PhD) диссертация автореферати. - Тошкент, 2019. - 22 б.

7. Speech by the President of the Republic of Uzbekistan Shavkat Mirziyoyev at the solemn ceremony dedicated to the 24th anniversary of the adoption of the Constitution of the Republic of Uzbekistan. - People's speech, December 8, 2016.

8. Siddikov, I. В. (2019). Философскопедагогические аспекты развития интеллектуальной культуры студентов. Вестник Ошского государственного университета, (3), 38-42. 